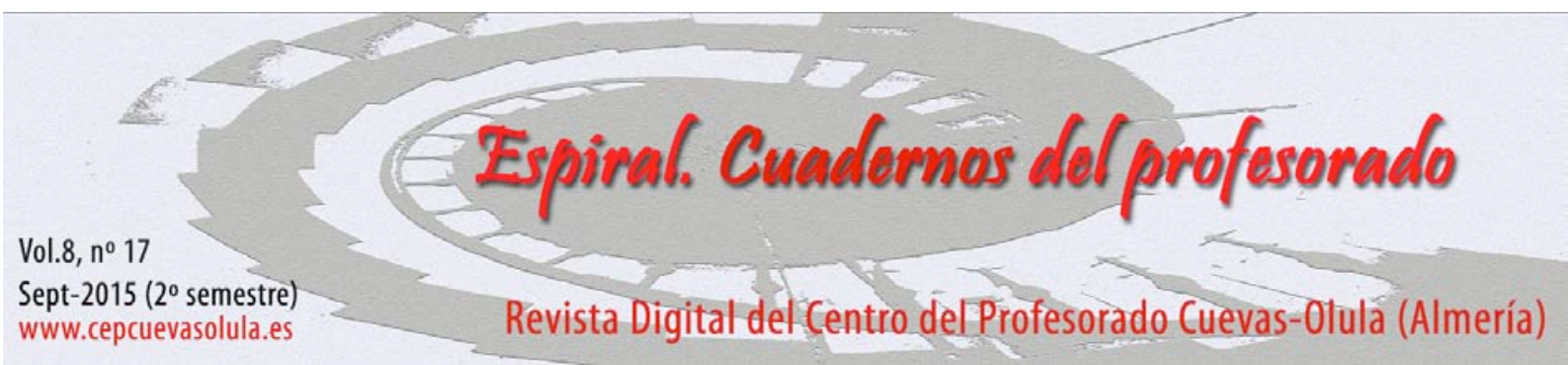

\title{
LEARNING COMMUNICATIVE COMPETENCES THROUGH CELEBRITY GOSSIP BLOGS
}

\author{
El aprendizaje de las competencias comunicativas a través de los blogs de cotilleos sobre \\ celebridades
}

\section{Margarita Esther Sánchez Cuervo}

IES Tamaraceite y Facultad de Formación del Profesorado, Universidad de Las Palmas de Gran Canaria, España

\begin{abstract}
Celebrity gossip blogs have become a stimulating discourse practice that mainly offers the latest news about celebs. Due to the great variety of gossip blogs that exist nowadays, bloggers try to attract readers with a continuous update of the news presented and, on many occasions, they employ doubtful sources to provide the freshest piece of information. As a result, these writers may attribute their words to these sources if the gossip is not truthful. Being a lively instance of language, the blogging exercise offers different opportunities to study the English language. The objectives of this study seek to improve the communicative competence in English of Baccalaureate Spanish students who have examined this discourse, following the Common European Framework of References for Languages. A qualitative methodology has been followed, based on a selection of blog entries chosen randomly. The conclusions show that students have developed their linguistic competence by considering some forms of speech presentation. They have also deepened their knowledge of the sociolinguistic competence by getting familiar with acronyms and the enallage of person that remind us of the spoken language. Finally, they have learned about the pragmatic competence by analysing illocutionary acts that are related to the occurrences of speech presentation.
\end{abstract}

Key words: celebrity gossip blogs, learning, communicative competences.

RESUMEN: Los blogs de cotilleos sobre celebridades resultan una práctica discursiva estimulante que ofrece las novedades sobre los famosos. La gran variedad de estos blogs permite a los blogueros atraer a sus lectores con la actualización frecuente de noticias, utilizando en ocasiones fuentes de procedencia dudosa. Como resultado, estos autores atribuyen a dichas fuentes noticias que no son demasiado fiables. Al ser una muestra de lengua dinámica, la práctica del blog brinda distintas oportunidades para estudiar el inglés como lengua extranjera. Los objetivos de este trabajo persiguen la mejora de la competencia comunicativa en inglés de un grupo de estudiantes de Bachillerato que ha examinado este discurso, siguiendo las directrices del Marco Común Europeo de Referencia para las Lenguas. Se ha seguido una metodología cualitativa, basada en una selección de entradas de blog escogidas al azar. Las conclusiones muestran que los estudiantes han desarrollado y mejorado su competencia lingüística al considerar algunas formas de presentación del discurso. También han profundizado en la competencia sociolingüística al familiarizarse con los acrónimos y la enálage de persona, que nos recuerdan al lenguaje oral. Finalmente, han aprendido sobre la competencia pragmática al analizar algunos actos de habla relacionados con la presentación del discurso.

Palabras clave: blogs de cotilleos sobre celebridades, aprendizaje, competencias comunicativas. 


\begin{tabular}{l}
\hline Sánchez Cuervo, M. E. (2015). Learning Communicative Competences through Celebrity Gossip \\
Blogs. Espiral. Cuadernos del Profesorado, 8(17), 17-26. Disponible en: \\
http://www.cepcuevasolula.es/espiral.
\end{tabular}

Fecha de recepción: 08/04/2015

Fecha de aceptación: 17/07/2015

Enviar correspondencia a:

margaritaesther.sanchez@ulpgc.es

\section{1.- INTRODUCCIÓN}

\section{The celebrity gossip blog: characteristics}

Nowadays chatting about gossip seems to be a major topic. Gossip is essential to establishing reputations and becomes a way to expose people's flouting of norms. It shapes a crucial instrument for a community to guarantee that its norms are respected. The Internet is transforming the nature and effects of gossip in so far as it is becoming more permanent and widespread, but it is not so selective when it comes to having a definite audience (Solove, 2007, pp. 63-74).

In particular, celebrity gossip blogs usually follow the same general format. A picture is posted, and this picture is accompanied by a comment, story, or a link to a more detailed article. If the picture is the focus of the post, the text influences the way in which the picture is received. Bloggers are altering the way that stars are consumed by the public by concentrating not only on the image itself, but also on its means of production (Petersen, 2007). As a result, they modify our expectations and understanding of stars and their relevance. With the advent of newspapers and magazines, the reader had to wait for a weekly update on the star's dynamic lifestyle. By means of the television, the audience was introduced to celebrity news like Entertainment Tonight and E! However, the Internet is now accessible nearly everywhere and at all times so that a consumer can check new entries several times a day. Petersen refers to Perez Hilton's blog as an example of both a detector of public disfavour and a catalyst for it. Hilton comes across pieces of gossip from diverse sources and spreads this news to an audience of millions. Although the famous blogger acknowledges that the gossip may be unlikely, his continued interest in the story cleverly influences the reader to believe that such behaviour may be attributed to the stars in question. As a result, the gossip blogger functions as a star manipulator, and contributes to emphasising the idea that Hollywood can manipulate any image to please the public.

Celebrity blogs are part of the commentary blog (Miller and Shepherd, 2004), and can be defined in four ways: (1) the typical commercial entertainment blog like Entertainment Weekly, which offers a mix of gossip and undercover publicity that is considered to be an extension of the traditional television show. (2) The DIY gossip blog that is fan-based like the successful Perez Hilton who criticises or praises celebrities. (3) The paparazzi agency blog site that offers the agencies' own celebrity pictures together with some improvised gossip and news, like X17 Online. (4) The personal social networking pages of celebrities that use commercial sites such as Myspace, Twitter or Flickr, and celebrities' own websites (McNamara, 2011, p. 524). In all cases, the audience are able to remark on the content presented. The bloggers become the voice of gossip but also wish that their words have an instant effect on the audience by means of provoking comments. However, there is no implication that the bloggers' words reflect the truth, or that the sources of information used to reveal that supposed truth are reliable. In trying to prompt an answer from the readers, bloggers often introduce dubious informants whose authority is not always provided and who are, in many cases, unidentified.

\section{Objectives}

This article studies the work on communicative competences in post-secondary education through the use of celebrity gossip blogs. In particular, it focuses on A2 level (or baccalaureate) Spanish students, aged from 17 to 18 years old, who take a voluntary two year programme before considering higher education or high-grade vocational training. Conventionally, the use of newspapers in education has been recurrent because of its focus on contextualised language. Similarly, celebrity 
gossip blogs offer stimulating material that attracts young readers and is continuously updated. Celebrity gossip blog material fulfils several objectives in this study:

1. It considers the educational potential of this discourse in the context of the Baccalaureate stage.

2. It transmits the English culture and, in particular, the industry of entertainment that revolves around cinema, TV and music.

3. Due to the variety of voices in the text, it can be examined to explore grammatical units like the reported speech and consider the illocutionary acts that are associated with that speech presentation.

4. It also brings about trendy topics reflected in a lively prose that presents similarities to the oral language.

Bearing in mind this information, the competences considered have tried to deepen the students' understanding of English as regards to their knowledge of the language and its use in different contexts.

\section{2.- METHODOLOGY}

\section{Corpus}

The corpus taken for this study contains sixty posts belonging to high-traffic celebrity gossip blogs during May 2010 and October 2012. The posts were chosen randomly, though trying not to repeat the same gossip about a specific celebrity so that the topics were more varied.

The sites are the following:

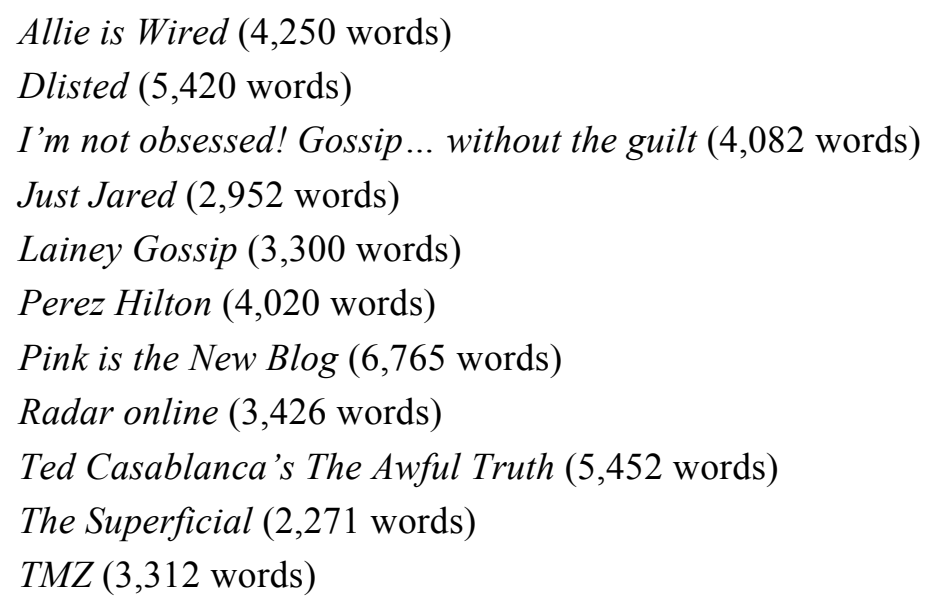

Eight of these sites are part of DYU gossip blogs whose writers decide on the celebs that they are going to speak about. In contrast, Radar online and TMZ are agency blogs that display their own graphic material and printed gossip.

\section{Participants}

The study group is comprised by 45 students, 29 of which belong to the Humanities and Social Sciences Baccalaureate and 16 belong to the Science and Technology Baccalaureate. Students have analysed the corpus manually, looking for samples that appear specified in their syllabus in order to improve their communicative competence in English. This procedure involved the manual analysis of small-scale text corpora. Furthermore, the data was collected qualitatively and analysed through content analysis method. This analysis implies the identification, categorisation, and classification of each example according to the competences studied (Miles and Huberman, 1994; Patton, 2002).

During two weeks, they looked for examples through a combination of discovery learning and cooperative learning approaches, bearing in mind the competences selected. Prior to their search, the 
review of concepts, the purpose of the study, teacher-student roles, method and evaluation were considered. The results were crosschecked by the teacher. The examples below have been selected as illustration for this study.

\section{3.- COMMUNICATIVE COMPETENCES STUDIED}

The Common European Framework of Reference for Languages (CEFR) establishes three types of communicative competences in language: linguistic, sociolinguistic and pragmatic.

- Linguistic competence refers to the user's knowledge of lexicon, phonology and syntax. This component is not only related to the significance and quality of the knowledge, but also with the cognitive organisation of the speaker, the way in which this knowledge is stored and its accessibility.

- Sociolinguistic competence has to do with the user's knowledge of the sociocultural conditions of the language. Bearing in mind the sensibility to social conventions, the sociolinguistic component affects the linguistic communication among representatives of different cultures.

- Pragmatic competence is related to the functional use of linguistic resources that are performed within communicative exchanges. It also has to do with the command of discourse, cohesion and coherence, the identification of types and forms of text, irony and parody.

The Baccalaureate stage, as reflected in the BOE (Official Bulletin of the State), includes the following contents related to the study of the communicative competences that appear summarised below:

- Use of complex grammatical structures and necessary functions to achieve proper communication in different situations, to explain the main points of an idea or a problem reasonably, and to express thoughts about abstract or cultural topics such as music and films.

- Identification of the communicative purpose, the textual and paratextual elements and the way in which the information of the text is structured.

- Recognition of the varieties of the language use, and of the differences between the formal and informal language, both oral and written.

- Use of adequate registers that are adapted to the addressee and his/her communicative intention, the channel and the means of communication.

- Awareness of the most important courtesy rules.

- Interest in establishing communicative exchanges and knowing the cultural information of those countries where the foreign language is spoken.

\section{Linguistic competence}

Students at this intermediate level have learned to classify reporting verbs into the following categories: statements, questions, orders and suggestions. They are supposed to express the different functions contained within these categories in the appropriate communicative context. Thus students have revised their previous knowledge and acquired a new taxonomy of learning based on Leech and Short's (2007) model of speech and thought presentation. Although this model was initially made for literary texts and starts from functional concerns, it establishes linguistic criteria that can be applied to a teaching context. In this study, the model proves to be useful as far as bloggers frequently report on what other people have said.

Taxonomy for speech presentation:

- Narrative report of speech (NRS): Paul agreed.

- Indirect speech (IS): Paul said that he agreed.

- Free indirect speech (FIS): Paul was in agreement. 
- Direct speech (DS): Paul said 'I agree'.

- Free direct speech (FDS): I agree.

Taxonomy for thought presentation:

- Narrative report of thought (NRT): Paul decided.

- Indirect thought (IT): Paul thought that he should do it.

- Free indirect thought (FIT): Paul should do it.

- Direct thought (DT): Paul thought 'I should do it'.

- Free direct thought (FDT): I should do it.

The following changes occur when converting from Direct Speech and Thought into indirect forms of speech:

- The inverted commas are removed.

"I'm travelling to Paris," he said.

He said that he was travelling to Paris.

- The speech is marked by a subordinator (e.g. "that").

"I'm going to buy the house by the seaside next month."

She told us that she was going to buy the house by the seaside the following month.

- Any first and second person pronouns change to third person.

- The direction of movement verbs change (e.g. "go - come").

"I'll go in a while," he promised.

He promised that he would come in a while.

- Any present tense verbs change to past (including auxiliaries). Tenses are placed in their 'backshifted' forms.

"I haven't studied for the exam."

She said that she hadn't studied for the exam.

- Any proximal deixis changes to distal (e.g. "this - that").

"Please, pass me this book."

He asked me to pass him that book.

In celebrity gossip blogs, the most frequent verbal forms relate to how the blogger transmits the information, that is to say, if the writer him/herself speaks, or if that information derives from someone else who is not the blogger. I include the following classification with its corresponding examples taken from the study (Sánchez-Cuervo, 2013a):

- Hearsay verbs: "claim", "say", "look like”, "tell”, “add”, "report”. For example:

1. The designer -- Philippe Starck -- claims the late Apple founder had agreed to pay him a fee that equaled $6 \%$ of the ship's building cost ... back when Jobs commissioned the yacht in 2009 ... but no formal contract was ever written up.

http://www.tmz.com/2012/12/21/steve-jobs-yacht-impounded// [Accessed December $212012]$

2. Our spy tells us Mandy seemed to think she accidentally cut someone else in line and so she let that person? as well as a couple others, just to be safe? order ahead of her. http://uk.eonline.com/news/183692/caught-mandy-moore-being-just-the-nicest-ever [Accessed June 12010 ]

- Mindsay verbs: "think", "know", "guess", "be sure". For example:

3. Sure, there were a few arm gropes here and there, some giggles and ear whisperings going on, but we don't think Bar has much to worry about. What's a bachelor to do when his go-to gal isn't around? Flirting only comes naturally for the stud. 
http://uk.eonline.com/news/182067/caught-is-leo-still-on-the-prowl [Accessed May 20 2010]

4. Sorry, Twi-Hards! We know how hard it is for you when all the behind the scenes dramz compromises the integrity (ha!) of the films! LOLZ!

http://perezhilton.com/2010-05-12-wtf-greene-and-lutz-want-how-much-for-breakingdawn\#.VG-4OclTBf8 [Accessed May 12 2010]

- Perception verbs: "seem", “appear", “look", “sound", “see”, “reveal”, “show", “confirm". For example:

5. See the way I remember it was that Hilary Duff looked really healthy. And then all of a sudden, around when she was dating Joel Madden, she looked really unhealthy.

http://www.laineygossip.com/Miley-Cyrus-on-holiday-with-dad-Billy-Ray-inMexico-May-2010/16851?celebrityId=20334 [Accessed May 25 2010]

6. "By setting a precedent and suing Closer, Prince William is making a stand for the future," a source previously revealed.

http://radaronline.com/exclusives/2012/09/kate-middleton-nude-photos-legal-feesfree-prince-william/ [Accessed September 17 2012]

Some categories have some formal features that distinguish them from the two traditional categories of direct and indirect speech presentation. For example, the narrative report of speech (NRS) does not include references to the real speech but it indicates the speech act used, as in "He promised". NRS often appears to avoid the report of a conversation that may not interest the reader. This category also entails the most intrusion by the narrator (Jeffries \& McIntyre, 2010, pp. 88-89). In (7), the blogger summarises the content of the conversations that has supposedly occurred between actress Tori Spelling and her former friends. It is improbable, however, that the blogger has access to private conversations, so he simply reports on the knowledge he possesses.

7. When Tori Spelling calls all her old 90210 cast mates, they either hang up on her face or pretend to be the maid and tell her they are dead and not to call again. That's because they are all co-presidents of the I HATE TORI SPELLING club. That's what Tori says anyway.

http://dlisted.com/2010/06/21/everybody-hates-tori/ [Accessed June 21 2010]

Whereas NRS represents a clear intrusion of the narratorial voice, the direct forms of speech and thought are not mediated by a reporter. In the discourse that I am considering, examples belonging to these categories are infrequent. It does not occur the same with indirect forms of speech and thought, where utterances must be carefully analysed inside context in order to decide whether they belong to the writer or the character under scrutiny. The forms belonging to free indirect speech usually merge the narrator's voice with the original speaker's voice. In (8), the reader can't be certain about who says "she's more than a sick body". It is possibly the blogger's voice but from a strictly linguistic perspective there is no clear evidence whether he is giving his opinion or he is reporting what the girl has said.

8. (...) Eva thinks it's more than just her looks. She told Allure that she's into art and reads the Fountainhead. Saying she reads Ayn Rand automatically means she's more than a sick body. As for that body...

http://www.laineygossip.com/SIT-DOWN-Eva-Mendes/17269 [Accessed 14 July 2010]

\section{Sociolinguistic competence}

Students have first delved into this competence by studying the acronyms that are found in the blogger's posts (Sánchez-Cuervo, 2013b, pp. 333-334). These terms are associated with a particular cultural milieu (Graff and Winn 2006, p. 54). Some typical acronyms are "LOL", "OMG" and "BFF" that appear as written conventions that may also be present in spoken registers (West-Brown, 2008, p. 
321). In the first example, the blogger mocks at the photo agency that affirms that the couple formed by John Krasinski and Emiliy Blunt are going on their honeymoon. The expression "LOL", meaning "laughing out loud" or "lots of laughter", stresses the writer's teasing comment:

9. Well, so says the photo agency. LOL! Newlyweds John Krasinski and Emily Blunt were spotted at LAX this afternoon. Reportedly, the couple is leaving on their honeymoon. It seems logical since they were married over the weekend, but I highly doubt they told the photographers where they were headed.

http://www.imnotobsessed.com/2010/07/13/john-krasinski-and-emily-blunt-leave-fortheir-honeymoon/ [Accessed July 13 2010]

In the following extract, the blogger is also making fun of one celebrity's attempt of suicide. Her inclusion of "Omg", which stands for "Oh my God!", suggests her enjoyment and, at the same time, her lack of concern for people who try to get attention from the media as a pastime.

10. When she got back home, she was angry with those who called authorities and took her "stunt" seriously! Omg. You know what they say about the boy who cried wolf. Something is seriously going to happen to her and then NOBODY is going to believe it because of all the incidents like this.

http://www.imnotobsessed.com/2010/06/07/tila-tequila-fakes-suicide-attempt-or-wasit-real/ [Accessed June 7 2010]

In this other example, the blogger refers to actress and singer Taylor Momsen and her controversial statement about her vibrator being her "BFF", that is, her "best friend forever":

11. In a recent interview, Taylor referenced her personal life, saying that her BFF is her vibrator. Perez Hilton felt the need to jump on the bandwagon, tweeting this: "@taylormomsen Instead of a vibrator, what you need is THIS http://twitpic.com/27bwo4".

http://allieiswired.com/archives/2010/07/taylor-momsen-fights-back-against-perezhilton/ [Accessed July 21 2010]

Apart from the search and further analysis of other acronyms found in the texts, students have also looked for other conversational features that are typical of some written genres like blogs and informal letters, and that may resemble the spoken ones. For example, the bloggers' use of the personal pronoun "we" in an attempt to include the readers' good favour. This technique of communion is the enallage of person from "I" to "we" (Graff and Winn, 2006, p. 57). It involves a change in the number of person, by which blogger and reader are joined in a collective "we". Readers feel supported by their inclusion into a virtual dialogue that is followed by their impending contribution to the blogger's posts.

This figure can be related with the notion of intersubjectivity, by which the author shares his/her knowledge with his/her audience. In the blog, readers feel compelled to participate in a virtual debate that poses opinions, not objective truths, which they can judge and interpret. Nuyts $(2001, \mathrm{p}$. 393) explains, to this respect, that the speaker may offer his/her evidence to a larger group of people who share the same conclusion. The author proposes two options: (1) the speaker alone has access to the evidence and draws his/her own conclusions; (2) the speaker indicates that the evidence is known to a larger group of people who share the same conclusion. In the second alternative, the speaker assumes "a shared responsibility among those people who have access to the evidence and accept the conclusions from it (including him/herself)".

For example, in (12), the author includes his readers to partake of his disapproval of actor Charlie Sheen's behaviour towards his ex-wife:

12. During all of this bad-blood domestic crap, we felt like we were the only ones wondering what the hell is happening to Brooke and Charlie's kids. And we may have found the answer in Richards... We know that Sheen surrendered legal custody of the children he had with Denise-Sam and Lola — to his ex-wife earlier this week. 
http://uk.eonline.com/uberblog/b179886 Denise Richards to the Rescue Come A gain .html [Accessed May 7 2010]

Similarly, in (13), the writer speculates about the real legal status of famous Demi Moore and Ashton Kutcher while incorporating his/her attentive audience:

13. As we previously reported, sources close to the couple have speculated that their Kabbalah wedding was just a symbolic ceremony and not a legal marriage, and her actions now seem to back up those claims.

http://radaronline.com/exclusives/2012/09/demi-moore-ashton-kutcher-legalmarriage-divorce/ [Accessed September 27 2012]

At the same time, the explicit reference to the addressee is usual in this piece of discourse, especially when the writer prompts readers to have a say in his/her posts. Therefore, the presence of "you" signals the dialogical nature of this discourse. In (14), for instance, the blogger begins her topic by calling her audience's attention to the celebrity in question, with the inclusion of the second personal pronoun:

14. If you've ever wondered why a talented actress like Lindsay Lohan has an addiction problem, all you have to do is look at her father Michael Lohan.

http://allieiswired.com/archives/2010/07/michael-lohan-sold-nude-photos-of-katemajor/ [Accessed July 25 2010]

\section{Pragmatic competence}

Students have approached the study of this competence through the analysis of illocutionary acts. Searle (1976) proposed five macro-classes of illocutionary act: representatives, directives, commissives, expressives and declaratives:

- Representatives commit the speaker to the truth of the expressed proposition. They typically include assertions, conclusions and hypotheses.

- Directives are attempts by the speaker to get the addressee to do something. These illocutionary acts cover requests, questions and invitations, among others.

- Commissives are illocutionary acts that commit the addressee to acting, to a future course of action. Some examples of commissives are promises, threats, and offers.

- Expressives usually transmit a psychological state like apologies, welcomes, and congratulations.

- Declaratives have an immediate change in the institutional state of affairs and normally rely on extra-linguistic institutions that provide rules for their use. Some examples include christening, excommunication and firing from work.

Students have paid special attention to representative illocutionary speech acts, which are the most numerous in the corpus (Coulthard, 1985, pp. 23-24). They have classified the utterances in relation to the most frequent verbal occurrences used for the report of speech that are shown above, those that contain hearsay verbs employed to convey the gossip.

Within hearsay verbs, they have made a distinction between neutral and illocutionary verbs. The first group contains verbs that present a 'saying' without being evaluated. Here we include verbs like "say" and "tell", which signal the illocutionary act. In contrast, the second group of verbs reflects the presence of the blogger in the text and is highly interpretive (Caldas-Coulthard, 1994, pp. 305306). Here we refer to verbs like "demand", "promise", "claim", and "report", which make clearer the illocutionary force of the blogger's quote.

Example (15) is found in the first group and presents the verb "says". The blogger relies on a "spy" to transmit the gossip about Mitt Romney and his wife on a cinema date. Example (16) also makes use of the neutral verbal form "tell". It belongs to the blog agency Radar, which offers some headlines in the post before unfolding the content. On this occasion, the writer passes his/her opinion to "sources" in order to distance himself/herself from the gossip. 
15. TMZ spies caught a glimpse of the wannabe Prez and wife Ann out at the movies in Del Mar, CA on Saturday night. Our spy says the couple was joined by two young men, but it's unclear who they were.

$\begin{array}{lll}\text { http://www.tmz.com/2012/11/18/mitt-romney-twilight-photo/ } & \text { [Accessed } & 18\end{array}$ November 2012]

16. Although Britney and Kevin share time with their children approximately 50/50, Kevin still has sole custody of the children. That will not change while Britney remains under the umbrella of a conservatorship. Kevin is not opposed to shared custody once that happens, sources tell us.

http://radaronline.com/exclusives/2010/06/exclusive-judge-discusses-child-custodyissues-britney-spears-dad-and-attorneys/ [Accessed June 6 2010]

Example (17) is included within the second group of representative speech acts, which contains illocutionary verbs. In the extract, the blogger relies on the blog agency TMZ to "report" the latest news about Lindsay Lohan. By using this verb, furthermore, the blogger detaches himself from what is being reported. The inclusion of the adverb "apparently" reinforces this view. Example (18) introduces the disturbing news about Steve Jobs" yatch "Venus". The reporter uses the verb "claimed" to rely on the ship designer's alleged complaints about "unpaid wages".

17. As I was typing this, TMZ reported that a bench warrant has been issued for Lindsay! Apparently her new bail amount will be $\$ 200,000$ and she's in trouble for FIVE violations of her probation.

http://www.imnotobsessed.com/2010/06/08/lindsay-lohan-furious-over-accusationsof-drinking--bench-warrant-issued/ [Accessed June 8 2010]

18. Steve Jobs' $\$ 197$ million super yacht "Venus" has been literally CHAINED to a dock in Amsterdam by Dutch authorities ... after the ship's designer claimed the Jobs family stiffed him on $\$ 4$ million in unpaid wages.

http://www.tmz.com/2012/12/21/steve-jobs-yacht-impounded/] [Accessed December 2012]

In the second group of illocutionary verbal forms we also encounter discourse-signalling verbs that are not reporting properly but often introduce forms of direct speech. "Add" and "continue" are some of these discourse-signalling forms that are found in the blogs that we are considering. In (19), the blogger comments on an incident that actor Alec Baldwin had on a plane and reproduces his words inserting the verb "add":

19. Alec just tweeted again, claiming he has just boarded a 3pm flight on American -adding, "The flight attendants already look... smarter."

http://www.tmz.com/2011/12/06/alec-baldwin-airplane-words-with-friends/ [Accessed June 2011]

\section{4.- CONCLUSIONS}

Gossip celebrity blogs exemplify a lively discourse that contains genuine and contextualised pieces of language. With this proposal, students have encountered a motivating and attractive approach to the English language that is not usually found in more academic discourses. They have also got familiar with popular culture elements related to entertainment and the world of celebs.

Students have used the corpus to practise several topics included in their Baccalaureate syllabus. On balance, they have improved the following aspects of their communicative competence:

- The linguistic competence that concerns the transformation of syntactic structures present in the practice of reported speech. In addition, they have learned a new taxonomy of speech and thought presentation through Leech and Short's model. They have looked for 
the most common occurrences in the report of gossip through a triple classification of hearsay, mindsay and perception verbs.

- The sociolinguistic competence that entails the use of certain structures like acronyms, associated with the playful tone of gossip blogs, and the enallage of person that allows to establish the communion between the blogger and his/her readers.

- The pragmatic competence that involves the recognition and further interpretation of certain illocutionary acts.

Some suggestions for further research include the ideological implications of the gossip blog that are mainly present in the study of indirect forms of speech. The range of voices and the ambiguity in the identity of characters may become a challenge for the students interested in the study of the different forms of speech presentation. They can also deepen their knowledge about the industry of entertainment that in the case of celebrity gossip is mainly concerned with news about cinema, television and music. They can distinguish between gossip pertaining to the stars' personal lives and their professional activities. Which is more frequent? To what extent are readers more interested in knowing about the person or about his/her occupation? As a result, they get to know some elements of the sociocultural competence. Likewise, the analysis and further interpretation of illocutionary acts reveal the strategies that bloggers use in order to manipulate and control information.

\section{5.- REFERENCES}

Caldas-Coulthard, C. R. (1994). On reporting reporting: the representation of speech in factual and factional narratives. In M. Coulthard (Eds.), Advances in Written Text Analysis (pp. 295-308). London and New York: Routledge.

Coulthard, M. (1985). An Introduction to Discourse Analysis. Longman, London.

Common European Framework of Reference for Languages. Retrieved from http://cvc.cervantes.es/obref/marco

Graff, R., y Winn, W. (2006). Presencing 'communion' in Chaïm Perelman's New Rhetoric. Philosophy and Rhetoric, 39, 1, 45-71.

Jeffries, L. y McIntyre, D. (2010). Stylistics. Cambridge University Press, Cambridge, Leech, G. y Short, M. (2007). Style in Fiction. $2^{\text {nd }}$ ed. Longman, London.

McNamara, K. (2011). The paparazzi industry and new media: the evolving production and consumption of celebrity news and gossip websites. International Journal of Cultural Studies, 14, 5, 515-530.

Miles, M., \& Huberman, M. (1994). Qualitative data analysis. Beverly Hills: Sage Publications.

Miller, C. y Shepherd, D. (2004). Blogging as social action: a genre analysis of the weblog. In L. Gurak, S. Antonijevic, L. Johnson, C. Ratliff, and J. Reyman (Eds.), Into the Blogosphere: Rhetoric, Community and the Culture of Weblogs, University of Minnesota Press, Minneapolis. Retrieved from http://blog.lib.umn.edu/blogosphere/blogging as social action a genre analysis of the weblog.html

Ministerio de Educación, Política Social y Deporte. Real Decreto 1467/2007, November 2, to establish the curriculum of Baccalaureate. Official Bulletin of the State, No. 147, 18/06/2008. 27515-27521.

Nuyts, J. (2001). Subjectivity as an evidential dimension in epistemic modal expressions. Journal of Pragmatics, $33,383-400$.

Patton, M. Q. (2002). Qualitative research \& evaluation methods (3rd ed.). Thousands Oaks, CA: Sage Publications.

Petersen, A. (2007). Celebrity juice, not from concentrate: Perez Hilton, gossip blogs, and the new star production. Jump Cut. A Review of Contemp. Media. 47. Retrieved from http://www.ejumpcut.org/archive/jc49.2007/PerezHilton/index.html

Sánchez Cuervo, Margarita E. (2013a). A didactic proposal for learning reported speech through celebrity gossip blogs. The European Conference on Education. Official Conference Proceedings, 473-487.

Sánchez Cuervo, Margarita E. (2013b). 'OMG. you ready?': rhetorical argumentation in celebrity gossip blogs. In H. van Belle, P. Gillaerts, B. van Gorp, D. van de Mieroop and K. Rutten (Eds.), Verbal and Visual Rhetoric in a Media World (pp. 329-345). Amsterdam: Leiden University Press.

Searle, J. (1976). A classification of illocutionary acts. Language in Society, 5, 1-23. 
Solove, D. J. (2007). The Future of Reputation. Gossip, Rumor and the Privacy of the Internet, London University Press, New Haven and London.

West-Brown, D. (2008). Paris Hilton, Brenda Frazier, blogs, and the proliferation of celebu-. American Speech, $83,3,312-325$.

\section{Blog websites}

Allie is Wired

http://allieiswired.com

Dlisted

http://www.dlisted.com.

I'm not obsessed! Gossip... without the guilt

http://www.imnotobsessed.com

Just Jared

http://justjared.buzznet.com

Lainey Gossip

http://www.laineygossip.com

Perez Hilton

http://perezhilton.com

Pink is the New Blog.

http://www.pinkisthenewblog.com

Radaronline.com

http://www.radaronline.com

Ted Casablanca's The Awful Truth

http://uk.eonline.com/uberblog/the awful truth/index.html

The Superficial

http://www.thesuperficial.com

$T M Z$

http://www.tmz.com/ 